agriTECH, 40 (4) 2020, 299-304

\title{
Karakteristik Fisika-Kimia Kulit Singkong Asal Samarinda dan Akseptabilitas Sensoris Keripiknya Sebagai Camilan Diet
}

\author{
Physicochemical Characteristics of Cassava Peel from Samarinda and It's \\ Acceptability for Diet Snack Chips \\ Krishna Purnawan Candra ${ }^{1 *}$ A. Ainudin ${ }^{1,2}$, Muhamad Arifin ${ }^{1,3,}$ Y. Yuliani ${ }^{1}$ \\ 1]urusan Teknologi Hasil Pertanian, Fakultas Pertanian, Universitas Mulawarman \\ Jl. Tanah Grogot, Kampus Gunung Kelua, Samarinda 75119, Indonesia \\ ${ }^{2}$ Dinas Pertanian Kabupaten Kutai Barat, Jl. Komplek Perkantoran, Sendawar, \\ Kabupaten Kutai Barat 75776, Indonesia \\ 3PT Anugerah Energitama, Palma Serasih Group, Kecamatan Muara Wahau, Kabupaten Kutai Timur, Indonesia \\ *Penulis korespondensi: Krishna Purnawan Candra, E-mail: candra@faperta.unmul.ac.id
}

Tanggal submisi: 5 Mei 2018; Tanggal penerimaan: 23 Maret 2020

\begin{abstract}
ABSTRAK
Tujuan penelitian ini adalah untuk menentukan karakteristik fisika-kimia kulit singkong dan akseptabilitas sensoris keripik kulit singkong dari tiga varietas singkong yang umum dibudidayakan di Samarinda, yaitu Singkong Pacar, Singkong Kuning/Mentega dan Singkong Buton. Tepung umbi ketiga singkong tersebut mempunyai kadar HCN berturut-turut sebesar 14,04; 12,02, dan 19,38 mg/kg. Penelitian ini disusun dalam Rancangan Acak Lengkap, masing-masing perlakuan diulang 9 kali. Parameter yang diamati adalah ketebalan, kadar air, kadar serat kasar, kadar abu kulit singkong, dan akseptabilitas sensoris hedonik dan mutu hedonik keripik kulit singkong yang dihasilkan (kerenyahan, rasa, aroma, dan warna). Hasil penelitian menunjukkan bahwa kecuali kadar air, kulit ketiga jenis singkong tersebut berbeda nyata $(p<0,05)$ untuk ketebalan, kadar air, kadar serat kasar dan kadar abunya. Kadar air kulit ketiga jenis singkong tersebut berkisar 66,70-70,07\%. Singkong Pacar, singkong Kuning/ Mentega, dan singkong Buton mempunyai ketebalan berturut-turut 1,52; 2,32, dan 1,84 mm; kadar serat 2,70; 2,18, dan 1,68\%; dan kadar abu 1,19; 1,30, dan 0,94\%. Jenis kulit ketiga singkong tersebut menghasilkan keripik dengan akseptabilitas sensoris hedonik dan mutu hedonik (kerenyahan, rasa, aroma dan warna) yang berbeda $(p<0,05)$. Kerenyahan dan rasa keripik kulit singkong yang paling disukai adalah keripik kulit singkong Pacar dengan nilai sensoris mutu hedonik untuk kerenyahan dan rasa 4,50 (skala 1-7, agak renyah mendekati renyah) dan 5,35 (skala 1-7, agak berasa singkong mendekati berasa singkong).
\end{abstract}

Kata kunci: Kulit singkong; keripik; camilan diet

\begin{abstract}
The aim of this research was to determine the physicochemical characteristics of cassava peel and the sensory acceptability of its chip form three varieties generally planted in Samarinda, e.g. Pacar, Kuning/Mentega, and Buton cassava. The flour of the three cassavas pulp has HCN content of $14.04,12.02$, and $19.38 \mathrm{mg} / \mathrm{kg}$. A single factor experiment arranged in Completely Randomized Design and each treatment was repeated nine times. Thickness, moisture content, crude fibre content, and ash content of the casava peel were observed, as well as hedonic and quality hedonic sensory acceptability of cassava peel chips for crispiness, taste, aroma, and colour. The result showed that except moisture content, the peel of the three cassava varieties was significantly different $(p<0.05)$ for the thickness, crude fibre content and ash content. The moisture content of the three cassava varieties was around $66.70-70.07 \%$. Peel of Pacar, Kuning/Mentega and Buton cassava has a thickness of $1.52,2.32$, and $1.84 \mathrm{~mm}$, the crude fibre content of $2.70,2.18,1.68 \%$, and ash content of $1.19,2.18$, and
\end{abstract}

DOI: http://doi.org/10.22146/agritech.35291

ISSN 0216-0455 (Print), ISSN 2527-3825 (Online) 
$0.94 \%$, respectively. The cassava peel chips of the three cassava varieties were significantly different $(p<0.05)$ for hedonic and quality hedonic acceptability (crispiness, taste, aroma, and colour). Pacar cassava showed the most acceptable for crispiness and taste, which has a hedonic and hedonic quality scale of 4.50 (1-7, crispy moderately to crispy) and 5.35 (1-7, taste moderately like cassava to taste like cassava).

Keywords: Cassava peel; chips; diet snack

\section{PENDAHULUAN}

Singkong (Manihot esculenta) merupakan sumber pangan yang tersebar di negara-negara tropis Asia dan Afrika. Singkong ini menjadi pangan sumber karbohidrat utama di Afrika bagian Barat, seperti Ghana, Nigeria, Kamerun dan Pantai Gading. Indonesia termasuk satu dari lima negara penghasil singkong utama disamping Nigeria, Brazil, Thailand, dan Republik Demokratik Kongo (IFAD dan FAO, 2000).

Setelah dipanen singkong tidak dapat bertahan lama (Sánchez dkk., 2013), sehingga biasanya langsung diolah menjadi produk olahan seperti gaplek, gari, tapioka, atau digunakan untuk bahan baku bioetanol (Falade dan Akingbala, 2010), sedangkan kulit umbinya merupakan limbah. Pemanfaatan kulit singkong yang paling dominan adalah sebagai pakan ternak (Ofuya dan Obilor, 1993; Osei dkk., 1990; Osei dan Twumasi, 1989), bahan arang aktif dan media tanam (MorenoPiraján dan Giraldo, 2010; Sivakumar dkk., 2001), dan media tumbuh mikroba untuk produksi enzim (Sani dkk., 1992; Silva dkk., 2009).

Saat ini usaha pengembangan potensi kulit umbi singkong sebagai bahan campuran pangan terus dilakukan dan telah dikembangkan dalam skala rumah tangga. Beberapa penelitian telah dilakukan untuk mendukung usaha ini, antara lain pemanfaatannya menjadi keripik (Sofiani, 2015), bahan substitusi roti dan aneka kue (Aini, 2013; Pratiwi, 2013), dan mie (Mahanany, 2013) tetapi publikasi ilmiahnya masih sangat jarang (Resimanuk dkk., 2018).

Kandungan serat yang cukup tinggi dari kulit umbi singkong sekitar 28,3-125,7 g/kg (Hermanto dan Fitriani, 2018; Okpako dkk., 2008; Olafadehan dkk., 2012) menjadi alasan perlunya pengembangan pengolahan kripik kulit singkong menjadi camilan diet, salah satunya adalah keripik. Akan tetapi kandungan HCN yang relatif tinggi dan bervariatif pada kulit singkong sekitar 40,33-710,98 mg/kg (Hermanto dan Fitriani, 2018; Okpako dkk., 2008; Olafadehan dkk., 2012) memerlukan perhatian khusus, yaitu pemilihan jenis singkong dengan kadar $\mathrm{HCN}$ yang rendah ataupun melalui perlakuan pendahuluan yang tepat. Berdasarkan kandungan $\mathrm{HCN}$-nya, varietas singkong yang dikenal di Indonesia digolongkan menjadi 3, yaitu singkong jenis pahit (> $100 \mathrm{mg} / \mathrm{kg}$ ), misalnya varietas Adira II, Adira IV dan Thailand, (ii) agak pahit (40-100 mg/kg), misalnya UJ-5, dan tidak pahit ( $<40 \mathrm{mg} / \mathrm{kg}$ ) seperti Adira I dan Manado (Prabawati dkk., 2011).

Penelitian ini adalah merupakan penelitian lanjutan tentang potensi tiga jenis singkong yang umum dibudidayakan di Samarinda (Sikkin dan Candra, 2015). Tujuan penelitian ini adalah menentukan karakteristik fisika-kimia kulit umbi singkong dari tiga jenis singkong yang umum dibudidayakan di Samarinda (Singkong Pacar, Singkong Kuning/Mentega, dan Singkong Buton) serta mendeskripsikan akseptibilitas sensoris keripiknya sebagai bahan camilan berserat tinggi.

\section{METODE PENELITIAN}

\section{Bahan dan Alat}

Singkong yang digunakan pada penelitian ini adalah singkong dengan umur satu tahun dengan ukuran yang seragam (Gambar 1.) yang diperoleh dari petani di Kelurahan Sempaja, Kota Samarinda. Tiga jenis singkong yang digunakan adalah singkong Buton, singkong Kuning, dan singkong Pacar. Minyak goreng, garam, dan kapur sirih diperoleh dari pasar tradisional di kota Samarinda. Alat yang digunakan adalah seperangkat alat pemotong, penggorengan, termometer, timbangan digital, oven, dan furnace.

\section{Rancangan Percobaan dan Analisis Data}

Penelitian ini adalah penelitian faktor tunggal (jenis singkong) yang disusun dalam rancangan acak lengkap dengan 9 kali ulangan untuk tiap perlakuannya. Tiga jenis singkong yang diteliti adalah singkong Pacar, singkong Kuning atau Mentega, dan singkong Buton. Parameter yang diamati adalah akseptabilitas sensoris keripik kulit singkong yang dihasilkan (kerenyahan, warna, rasa, dan aroma), dan sifat fisika-kimia kulit singkong (ketebalan, kadar air, kadar serat kasar dari kulit singkong segar) yang digunakan. Sebagai tambahan data dilakukan juga pengamatan kadar HCN dari tepung daging umbi ketiga jenis singkong tersebut.

Data karakteristik fisika-kimia dianalisis dengan ANOVA dilanjutkan dengan Uji post-hoc Beda Nyata Terkecil untuk level perlakuan yang menunjukkan 
perbedaan nyata $(p<0,05)$. Data sensoris dianalisis dengan statistika non-parametrik (uji Kruskal-Wallis) dilanjutkan dengan uji Mann-Whitney $(p<0,10)$.

\section{Penyiapan Keripik Kulit Umbi Singkong}

Singkong dipilih dan disortasi yang sehat, bersih dan bebas dari penyakit. Singkong segar yang diperoleh kemudian dicuci dari kotoran tanah yang masih menempel dan dikupas kulitnya. Kulit umbi singkong diperoleh dari umbi singkong dalam bentuk memanjang menggunakan pisau tajam agar kulit tidak rusak. Kulit umbi singkong dicuci dengan air mengalir untuk menghilangkan kotoran, kemudian dilakukan perendaman dalam air garam ( $30 \mathrm{~g} / \mathrm{L}$ air) sebanyak 2 kali volume per berat bahan untuk menghilangkan rasa pahit pada kulit umbi singkong. Setelah 3 hari, kulit umbi singkong dibilas dan dilanjutkan dengan perendaman dalam air kapur sirih $(0,25 \mathrm{~g} / \mathrm{L}$ air) sebanyak 2 kali volume per berat bahan selama 20 menit. Setelah ditiriskan dilakukan penggorengan selama 10 menit dalam minyak dengan suhu $170^{\circ} \mathrm{C}$ (diukur dengan termometer). Keripik kulit singkong yang benar-benar matang adalah kuning kecokelatan.

\section{Penyiapan tepung umbi singkong tanpa kulit}

Tepung umbi singkong tanpa kulit disiapkan untuk menguji kadar HCN. Singkong dipotong-potong menjadi beberapa bagian, dan ditimbang sebanyak $500 \mathrm{~g}$ untuk setiap sampel. Untuk mencegah proses pencoklatan (browning) maka singkong yang telah dikupas direndam dalam air. Potongan singkong dicuci kembali dengan air bersih, kemudian dilakukan proses pengirisan dengan alat pengiris. Setelah dilakukan pengirisan diperoleh irisan basah dari singkong dan kemudian dilakukan pengeringan menggunakan oven listrik dengan suhu $60{ }^{\circ} \mathrm{C}$ selama 6 jam. Chip singkong yang telah kering dihaluskan dengan blender dan diayak dengan ayakan berukuran 100 mesh. Dari proses ini dihasilkan sebanyak $150 \mathrm{~g}$ tepung singkong.

\section{Pengujian}

Ketebalan kulit singkong segar diukur dengan mikrometer sekrup. Kadar air kulit singkong segar ditentukan dengan menggunakan metode oven (Sudarmadji dkk., 2010), kadar abu dan serat kasarnya ditentukan dengan metode SNI 01-2891-1992 (Badan Standardisasi Nasional, 1992) dan kadar HCN dianalisis sesuai metode yang disarankan oleh Sudarmadji dkk., 2010)

Akseptabilitas sensoris hedonik dan mutu hedonik (atribut yang diamati meliputi kerenyahan, warna, rasa, dan aroma) ditentukan oleh 15 orang panelis semi terlatih (Soekarto, 1985), yaitu mahasiswa yang telah mengambil dan lulus Mata Kuliah Uji Sensoris dan mendapatkan pelatihan berkaitan dengan uji organoleptik yang dilakukan pada percobaan ini sebelum melakukan pengujian sensoris. Kriteria lain bagi panelis adalah biasa mengkonsumsi keripik singkong.

Skala sensoris yang digunakan adalah 1-7, yaitu sangat tidak suka, tidak suka, agak tidak suka, agak suka, suka, sangat suka, dan amat sangat suka untuk uji sensoris hedonik. Sedangkan uji sensoris mutu hedonik dengan skala 1-7 untuk rasa adalah sangat berasa pahit, berasa pahit, berasa kelat, berasa serat, agak berasa singkong, berasa singkong, sangat berasa singkong; Untuk aroma adalah amat sangat tidak beraroma singkong, sangat tidak beraroma singkong, tidak beraroma singkong, agak tidak beraroma singkong, agak beraroma singkong, beraroma singkong, sangat beraroma singkong; Untuk warna adalah sangat cokelat, cokelat kemerahan, cokelat, agak cokelat, agak kuning, kuning, kuning kecokelatan; Untuk kerenyahan adalah sangat tidak renyah, tidak renyah, agak tidak renyah, agak renyah, renyah, angat renyah, amat sangat renyah.

\section{HASIL DAN PEMBAHASAN}

\section{Karakteristik Fisika-Kimia Kulit Umbi Singkong}

Umbi singkong yang digunakan dan keripik kulit singkong yang dihasilkan pada penelitian ini disajikan pada Gambar 1. Karakteristik fisika-kimia kulit umbi dari ketiga jenis singkong yang diteliti menunjukkan perbedaan yang nyata $(p<0,05)$, kecuali kadar air (Tabel 1). Kadar air ketiga jenis singkong tersebut berkisar antara 66,70-70,07\%.

Singkong Pacar merupakan jenis singkong yang mempunyai potensi paling besar untuk dijadikan sebagai bahan baku kripik karena mempunyai ketebalan paling tipis $(1,52 \mathrm{~mm})$, mempunyai kadar serat kasar dan abu paling tinggi, yaitu $2,70 \%$ dan 1,19\%. Hal ini untuk memenuhi karakteristik keripik kulit umbi singkong yang dikehendaki, yaitu renyah tetapi mengandung kadar serat yang tinggi. Keripik kulit umbi singkong Pacar ini mempunyai kerenyahan yang paling tinggi dibanding kedua keripik kulit umbi singkong yang lain (Tabel 2).

Kadar serat kulit umbi ketiga singkong asal Samarinda tersebut lebih tinggi dari kadar serat kulit umbi singkong pahit ("bitter") dari Nigeria (Manihot esculenta TMS 30572) yang hanya mempunyai kadar serat kasar sebesar 0,11\% (Eze dan Azubuike, 2010; Olafadehan dkk., 2012).

Tepung singkong Pacar, Mentega/Kuning dan Buton mempunyai kadar $\mathrm{HCN}$ berturut-turut sebesar 14,$04 ; 12,02 ;$ dan 19,38 mg/kg. Kadar HCN pada kulit 
umbi singkong dapat lebih tinggi dibanding pada daging umbinya (pulp). Kadar HCN bagian-bagian singkong segar, yaitu akar, daging dan kulit berturut-turut adalah 416, 200, dan $815 \mathrm{mg} / \mathrm{kg}$. Kadar HCN tersebut berubah karena proses pengeringan menjadi 64,31 , dan 1.250 $\mathrm{mg} / \mathrm{kg}$ untuk pengeringan dengan oven dan 42, 27, dan $322 \mathrm{mg} / \mathrm{kg}$ untuk pengeringan dengan sinar matahari (Morgan dan Choct, 2016).

Beberapa perlakuan juga dapat menurunkan kadar HCN pada kulit singkong seperti perendaman selama 4 hari dan 8 hari dalam larutan ragi yang ditambahkan gula (Hermanto dan Fitriani, 2018) berhasil menurunkan kadar HCN kulit singkong sebesar 99,4\% (dari 153 menjadi $0,88 \mathrm{mg} / \mathrm{kg}$ ) dan 99,8\% (dari 153 menjadi $0,37 \mathrm{mg} / \mathrm{kg}$ ). Perendaman daging umbi (pulp) singkong dalam air selama 3 hari dapat menurunkan kadar HCN sebesar $90,1 \%$ (dari 253,6 menjadi $25,0 \mathrm{mg} / \mathrm{kg}$ ) dan sebesar $99.2 \%$ (dari 25,6 menjadi 2,0 mg/kg) bila dilakukan perlakuan pengadukan (Yerizam dkk., 2018).

Perlakuan pendahuluan dengan merendam kulit singkong dalam air selama 5 hari menghasilkan tepung kulit singkong dengan kadar $\mathrm{HCN}$ paling rendah (turun $86,2 \%$ dari 710,98 menjadi $98,10 \mathrm{mg} / \mathrm{kg}$ ) dibanding tanpa perlakuan (turun $76,7 \%$ dari 710,98 menjadi

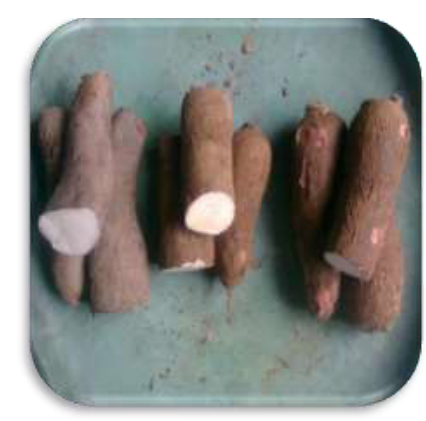

(a) (b) $\quad$ (c)

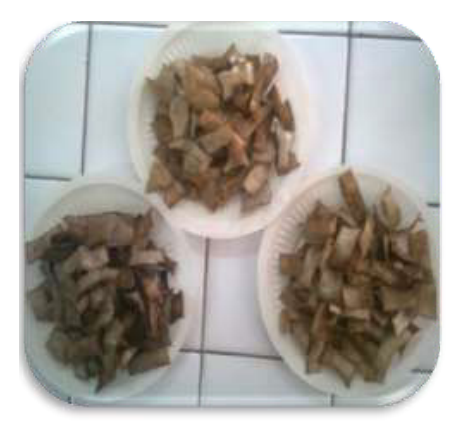

(a) (b) (c)
Gambar 1. Umbi singkong yang digunakan dan keripik kulit singkong yang dihasilkan pada penelitian ini. (a) Singkong Pacar, (b) singkong Kuning/Mentega, dan (c) singkong Buton.
$165,36 \mathrm{mg} / \mathrm{kg}$ ) atau dengan fermentasi padat selama 5 hari (turun 57,9\% dari 710,98 menjadi 299,21 mg/ kg) (Olafadehan dkk., 2012). Tepung kulit singkong diperoleh dengan penghalusan dari kulit singkong yang terlebih dahulu dikeringkan selama 5 hari dengan penjemuran.

Proses pengolahan keripik kulit singkong yang dilakukan pada penelitian ini adalah perlakuan perendaman kulit singkong selama 3 hari dalam air garam yang dilakukan untuk menurunkan kadar HCN sekaligus ditujukan untuk meningkatkan akseptabilitas sensoris hedonik untuk rasa. Olafadehan dkk. (2012) menyatakan bahwa konsentrasi HCN dalam diet tepung kulit singkong dan intake HCN berturut-turut sebesar 56 dan $4 \mathrm{mg} / \mathrm{kg}$ berat badan kelinci tidak memberikan efek toksik. Hal ini memberikan dukungan bahwa keripik kulit singkong yang dihasilkan pada penelitian ini adalah aman untuk kesehatan (kandungan HCN-nya tidak melewati ambang batas konsumsi).

\section{Akseptabilitas Sensoris Keripik Kulit Umbi Singkong}

Jenis singkong yang diuji memberikan pengaruh terhadap semua akseptibilitas sensoris hedonik dan mutu hedonik yang diamati (kerenyahan, rasa, aroma, dan warna). Masing-masing jenis singkong memberikan akseptibilitas sensoris yang berbeda sifatnya (Tabel 2.). Dari tiga jenis singkong tersebut, dua jenis singkong (singkong Pacar dan singkong Kuning/Mentega) memberikan nilai sensoris paling tinggi untuk parameter sensoris tertentu.

Kulit umbi Singkong Pacar mempunyai nilai sensoris hedonik (skala 1-7) tertinggi untuk kerenyahan $(4,36)$ dan rasa $(4,25)$, keduanya berkisar pada agak suka medekati suka. Sedangkan kulit Singkong Kuning memberikan nilai sensoris hedonik tertinggi (skala $1-7)$ untuk aroma $(4,54)$ dan warna $(4,22)$, keduanya berkisar pada agak suka mendekati suka.

Tabel 1. Karakteristik fisika-kimia kulit umbi dari tiga jenis singkong

\begin{tabular}{|c|c|c|c|}
\hline Karakteristik & Pacar & Kuning/Mentega & Buton \\
\hline Ketebalan (mm) & $1,52 \pm 0,03^{c}$ & $2,32 \pm 0,06^{a}$ & $1,84 \pm 0,04^{b}$ \\
\hline Kadar air (\%) & $67,33 \pm 0,58$ & $70,07 \pm 0,84$ & $66,70 \pm 1,62$ \\
\hline Kadar serat kasar (\%) & $2,70 \pm 0,07^{a}$ & $2,18 \pm 0,12^{b}$ & $1,68 \pm 0,04^{c}$ \\
\hline Kadar abu (\%) & $1,19 \pm 0,02^{\mathrm{a}}$ & $1,30 \pm 0,02^{\mathrm{a}}$ & $0,94 \pm 0,06^{b}$ \\
\hline Kadar HCN (mg/kg)* & $14,04 \pm 0,66^{b}$ & $12,02 \pm 0,90^{c}$ & $19,38 \pm 0,0,64^{\circ}$ \\
\hline
\end{tabular}

Keterangan: Nilai (rerata \pm std error) diperoleh dari 9 ulangan, kecuali untuk kadar HCN yang diperoleh dari 4 ulangan. Data pada baris yang sama yang diikuti dengan huruf berbeda menunjukkan berbeda nyata (Uji BNT, $p$ $<0,05)$. *)Dihitung dari tepung umbi singkong. 
K. P. Candra, dkk. / agriTECH 40 (4) 2020 299-305

Tabel 2. Sifat sensoris hedonik dan mutu hedonik kripik kulit singkong dari beberapa jenis singkong

\begin{tabular}{ccccc}
\hline \multirow{2}{*}{ Sifat Sensoris } & \multirow{2}{*}{ Parameter sensoris } & \multicolumn{3}{c}{ Nilai sensoris dari jenis kulit singkong } \\
\cline { 3 - 5 } & Kerenyahan & Pacar & Kuning/Mentega & Buton \\
\hline \multirow{3}{*}{ Hedonik $^{1)}$} & Rasa & $4,36^{\mathrm{a}}$ & $3,77^{\mathrm{c}}$ & $4,10^{\mathrm{b}}$ \\
& Aroma & $4,25^{\mathrm{a}}$ & $4,06^{\mathrm{b}}$ & $3,76^{\mathrm{c}}$ \\
& Warna & $4,47^{\mathrm{b}}$ & $4,54^{\mathrm{a}}$ & $4,24^{\mathrm{c}}$ \\
& Kerenyahan & $3,82^{\mathrm{b}}$ & $4,22^{\mathrm{a}}$ & $3,02^{\mathrm{c}}$ \\
\multirow{3}{*}{ Mutu Hedonik $^{2)}$} & Rasa & $4,50^{\mathrm{a}}$ & $4,18^{\mathrm{c}}$ & $4,28^{\mathrm{b}}$ \\
& Aroma & $5,35^{\mathrm{a}}$ & $5,01^{\mathrm{b}}$ & $4,77^{\mathrm{c}}$ \\
& Warna & $4,40^{\mathrm{b}}$ & $4,56^{\mathrm{a}}$ & $4,36^{\mathrm{c}}$ \\
& & $4,16^{\mathrm{b}}$ & $4,64^{\mathrm{a}}$ & $2,84^{\mathrm{c}}$ \\
\hline
\end{tabular}

Keterangan: Data dianalisis dengan Uji Kruskal-Wallis. Nilai sensoris merupakan rerata dari 135 data (9 ulangan yang diuji oleh 15 panelis). Nilai pada baris yang sama yang diikuti oleh huruf yang berbeda menunjukkan berbeda nyata (Uji MannWhitney, $p<0,1)$. Skala hedonik (1-7): Sangat tidak suka - Amat sangat suka. Skala mutu hedonik (1-7): kerenyahan (sangat tidak renyah-amat sangat renyah); rasa (sangat pahit-sangat berasa singkong); aroma (amat sangat tidak beraroma singkongsangat beraroma singkong); dan warna (sangat coklat-kuning kecoklatan).

Begitu pula untuk akseptabilitas sensoris mutu hedoniknya. Kulit umbi singkong Pacar mempunyai nilai sensoris mutu hedonik (skala 1-7) tertinggi untuk kerenyahan $(4,50$, berkisar pada agak renyah mendekati renyah) dan rasa $(5,35$, agak mendekati rasa singkong mendekati rasa singkong). Sedangkan kulit umbi Singkong Kuning/Mentega mempunyai nilai sensoris mutu hedonik (skala 1-7) tertinggi untuk aroma (4,56, berkisar pada agak tidak beraroma singkong mendekati beraroma singkong) dan warna (4,64, berkisar agak coklat mendekati agak kekuningan).

Kerenyahan keripik singkong pada umumnya ditentukan oleh kadar seratnya. Pemilihan singkong yang tidak terlalu tua (12 bulan) diperlukan agar kadar serat umbi singkongnya rendah sehingga diperoleh kerenyahan yang baik (Sikkin dan Candra, 2015). Hal yang berbeda ditemui pada penelitian ini. Singkong Pacar yang mempunyai kadar serat paling tinggi diantara 3 jenis singkong yang digunakan mendapat respon sensoris hedonik dan mutu hedonik untuk kerenyahan yang paling tinggi. Ketebalan kulit singkong memberikan jawaban yang konsisten baik untuk respon hedonik maupun respon mutu hedonik. Kerenyahan keripik kulit singkong makin baik selaras dengan makin tipisnya kulit singkong. Respon sensoris hedonik dan mutu hedonik kerenyahan keripik kulit singkong diperoleh dari keripik kulit singkong Pacar adalah 4,36 (tebal 1,53 mm) disusul oleh keripik kulit singkong Buton 4,10 (tebal 1,84 mm) dan keripik kulit singkong Mentega/Kuning 3,77 (tebal 2,32 mm).

Dari hasil ini maka kulit dari Singkong Pacar lebih direkomendasikan untuk dijadikan bahan baku pembuatan keripik kulit singkong berdasarkan sifat fisiko-kimia dan sensorisnya yang relatif lebih baik untuk karakteristik produk keripik.

\section{KESIMPULAN}

Dari tiga jenis singkong yang diteliti (singkong Pacar, Mentega/Kuning dan Buton), singkong Pacar mempunyai kulit yang paling potensial untuk dijadikan bahan baku keripik. Kulit singkong Pacar mempunyai ketebalan 1,52 mm, kadar air 67,33\%, kadar serat kasar $2,70 \%$, dan kadar abu 1,19\%. Akseptibilitas sensoris hedonik (skala 1-7) untuk kerenyahan, rasa, dan warna berkisar pada agak suka mendekati suka dengan nilai berkisar pada 4,25-4,27, dan untuk aroma mendekati agak suka dengan nilai 3,82. Akseptibilitas sensoris mutu hedonik keripik dari kulit singkong Pacar ini untuk kerenyahan adalah 4,36 (agak renyah mendekati renyah), untuk rasa adalah 5,36 (agak terasa singkong mendekati rasa singkong), untuk aroma adalah 4,40 (agak tidak beraroma singkong mendekati beraroma singkong), dan untuk warna 4,16 (agak kecoklatan mendekati agak kekuningan).

\section{KONFLIK KEPENTINGAN}

Semua penulis menyatakan tidak terdapat konflik kepentingan dalam penulisan artikel ini.

\section{DAFTAR PUSTAKA}

Aini, L. N. (2013). Substitusi Tepung Kulit Singkong Rendah HCN Pada Pembuatan Roti Tawar. Skripsi. Universitas 
Gadjah Mada. Retrieved from http://etd.repository. ugm.ac.id/index.php?mod=penelitian_detail\&sub=Pen elitianDetail\&act=view\&typ=html\&buku_id $=65493 \quad[20$ Desember 2015]

Badan Standardisasi Nasional. (1992). Cara Uji Makanan Dan Minuman SNI 01-2891-1992. Badan Standardisasi Nasional, Jakarta.

Pratiwi, I.D. (2013). Pengaruh substitusi tepung kulit singkong terhadap kualitas muffin. Food Science and Culinary Education Journal, 2(1), 17-23.

Eze, S.O., \& Azubuike, A. (2010). Assessment of the physicochemical properties and application of some cassava varieties. Research Journal of Applied Science, 5(4), 309-314.

Falade, K.O., \& Akingbala, J.O. (2010). Utilization of Cassava for Food. Food Reviews International, 27(1), 51-83. https://doi.org/10.1080/87559129.2010.518296

Hermanto, \& Fitriani. (2018). Pengaruh lama proses fermentasi terhadap kadar asam sianida ( $\mathrm{HCN}$ ) dan kadar protein pada kulit dan daun singkong. Jurnal Riset Teknologi Industri, 12(2), 169-180.

IFAD, \& FAO. (2000). The World Cassava Economy: Facts, trends and outlook. FAO Corporate. Rome: IFAD FAO. Retrieved from http://www.fao.org/docrep/009/x4007e/ x4007e00.htm [20 Desember 2015]

Mahanany, D. (2013). Pemanfaatan Tepung Kulit Singkong Sebagai Bahan Substitusi Pembuatan Mie Basah Ditinjau Dari Elastisitas Dan Daya Terima. Naskah Publikasi. Program Studi DIII Gizi Fakultas Ilmu Kesehatan Universitas Muhammadiyah Surakarta, Surakarta. https://doi.org/10.1007/s13398-014-0173-7.2

Moreno-Piraján, J.C., \& Giraldo, L. (2010). Study of activated carbons by pyrolysis of cassava peel in the presence of chloride zinc. Journal of Analytical and Applied Pyrolysis, 87(2), 288-290. https://doi.org/10.1016/j. jaap.2009.12.003

Morgan, N.K., \& Choct, M. (2016). Cassava: Nutrient composition and nutritive value in poultry diets. Animal Nutrition, 2(4), 253-261. https://doi.org/10.1016/j. aninu.2016.08.010

Ofuya, C.O., \& Obilor, S.N. (1993). The suitability of fermented cassava peel as a poultry feedstuff. Bioresource Technology, 44(2), 101-104. https://doi. org/10.1016/0960-8524(93)90181-A

Okpako, C.E., Ntui, V.O., Osuagwu, A.N., \& Obasi, F.I. (2008). Proximate composition and cyanide content of cassava peels fermented with Aspergillus niger and Lactobacillus rhamnosus. Journal of Food, Agriculture and Environment, 6(2), 251-255.

Olafadehan, O.A., Olafadehan, O.O., Obun, C.O., Yusuf, A.M., Adewumi, M.K., Omotugba, S.K., \& Daniel, N.E. (2012). Influence of processing cassava peels on the hydrogen cyanide concentration, nutritive value and performance of growing rabbits. Tropical Animal Health and Production, 44(2), 285-291. https://doi.org/10.1007/ s11250-011-0016-X

Osei, S.A., Asiamah, M., \& Atuahene, C.C. (1990). Effects of fermented cassava peel meal on the performance of layers. Animal Feed Science and Technology, 29(3-4), 295-301. https://doi.org/10.1016/03778401(90)90035-7

Osei, S. A., \& Twumasi, I. K. (1989). Effects of oven-dried cassava peel meal on the performance and carcass characteristics of broiler chickens. Animal Feed Science and Technology, 24(3-4), 247-252. https://doi. org/10.1016/0377-8401(89)90146-6

Prabawati, S., Richana, N., \& Suismono. (2011). Inovasi pengolahan singkong meningkatkan pendapatan dan diversifikasi pangan. Sinartani. Jakarta. Retrieved from www.litbang.deptan.go.id. [20 Desember 2015]

Resimanuk, Y.H., Nizar, A., \& Despita, R. (2018). Pemanfaatan limbah kulit singkong menjadi dendeng kulit singkong dengan penambahan berbagai sumber protein. Jurnal Agriekstensia, 17(1), 1-9.

Sánchez, T., Dufour, D., Moreno, J.L., Pizarro, M., Aragón, I.J., Domínguez, M., \& Ceballos, H. (2013). Changes in extended shelf life of cassava roots during storage in ambient conditions. Postharvest Biology and Technology, 86, 520-528. https://doi.org/10.1016/j. postharvbio.2013.07.014

Sani, A., Awe, F.A., \& Akinyanju, J.A. (1992). Amylase synthesis in Aspergillus flavus and Aspergillus niger grown on cassava peel. Journal of Industrial Microbiology, 10(1), 55-59. https://doi.org/10.1007/BF01583634

Sikkin, A.H., \& Candra, K.P. (2015). Sifat fisiko-kimia tiga jenis singkong (Manihot esculenta) dan sifat sensoris keripik yang dihasilkan: Studi kasus pengrajin keripik singkong di Samarinda. Jurnal Teknologi Pertanian Universitas Mulawarman, 10(1), 36-40.

Silva, T.M., Alarcon, R.F., Damasio, A.R. de L., Michelin, M., Maller, A., Masui, D. C., Terenzi, H.F., Jorge, J.A., Polizeli, M. de L.T.M. (2009). Use of Cassava peel as carbon source for production of amylolytic enzymes by Aspergillus niveus. International Journal of Food Engineering, 5(5), 1556-1558. https://doi.org/10.2202/1556-3758.1629

Sivakumar, S., Senthilkumar, P., \& Subburam, V. (2001). Carbon from Cassava peel, an agricultural waste, as an adsorbent in the removal of dyes and metal ions from aqueous solution. Bioresource Technology, 80(3), 233235. https://doi.org/10.1016/S0960-8524(00)00179-6

Soekarto, S.T. (1985). Penilaian Organoleptik untuk Industri Pangan dan Hasil Pertanian. Bhratara Karya Aksara, Jakarta.

Sofiani, F.R. (2015). Pengaruh Bahan Perendam Yang Berbeda Terhadap Kualitas Keripik Kulit Singkong. Skripsi. Jurusan 
K. P. Candra, dkk. / agriTECH 40 (4) 2020 299-305

Tata Boga - Fakultas Teknik UM. Universitas Negeri Malang. Retrieved from http://karya-ilmiah.um.ac.id/ index.php/Skripsi-Tata-Boga/article/view/38962

Sudarmadji, S., Haryono, B., \& Suhardi. (2010). Prosedur Analisa Bahan Makanan dan Pertanian. Liberty, Yogyakarta.
Yerizam, M., Zarman, M., \& Manggala, A. (2018). Reduksi HCN didalam singkong Karet (Manihot glaziovii) dengan proses perendaman. Jurnal Teknik Kimia, 24(3), 60-64. 